of human $\alpha_{2}$ macroglobulin without hydrolysis of the internal thiolesters or expression of the receptor recognition site. J Biol Chem 263:468-471

41. Pratt CW, Church FC, Pizzo SV 1988 In vivo catabolism of heparin cofactor II and its complex with thrombin: evidence for a common receptor-mediated clearance pathway for three serine protease inhibitors. Arch Biochem Biophys 22:111-117

42. Perlmutter DH, Joslin G, Nelson P, Schasteen CS, Adam SA, Fallon RJ 1990 Endocytosis and intracellular degradation of $\alpha_{1}$ antitrypsin-protease complexes is mediated by the SEC receptor. $\mathbf{J}$ Biol Chem 265:16713-16716
43. Twumasi DY, Liener IE, Goldston M, Levytska V 1977 Activation of human leukocyte elastase by human $\alpha_{2}$-macroglobulin. Nature 267:61-63

44. Banda MJ, Rice AG, Griffin GL, Senior RM $1988 \alpha_{1}$-proteinase inhibitor is a neutrophil chemoattractant after proteolytic inactivation by macrophage elastase. J Biol Chem 263:4481-4484

45. Banda MJ, Rice AG, Griffin GL, Senior RM 1988 The inhibitory complex of human $\alpha_{1}$-proteinase inhibitor and human leukocyte elastase is a neutrophil chemoattractant. J Exp Med 167:1608-1615

\title{
Announcement
}

\section{Annual Meeting of the European Society for Pediatric Research 1991}

The European Society for Pediatric Research (ESPR) will hold its next meeting in Zürich, Switzerland, September 1-4, 1991. The European Society of Pediatric Allergy and Clinical Immunology and the European Society of Magnetic Resonance in Neuropediatrics will join the ESPR. Satellite postgraduate courses and a symposium will be organized by these two societies on September 1 and September 5.

The main topics of the ESPR meeting are: therapeutic interventions in immune-mediated diseases, connective tissue, energy metabolism, and circulation of the neonatal brain.

Deadline for submitting abstracts is April 15, 1991.

For information, contact: Gabriel Duc, University Hospital of Zürich, Frauenklinikstrasse 10, ZH-8091 Zürich, Tel. + 41125553 40, Telefax + 4112554442. 